\title{
ОХРАНА СЕЛЬСКОХОЗЯЙСТВЕННЫХ УГОДИЙ В ХОЗЯЙСТВУЮЩЕМ СУБЪЕКТЕ С ПРИМЕНЕНИЕМ ЦИФРОВЫХ ТЕХНОЛОГИЙ
}

\author{
E.P. Krupochkin, O.E. Merzlyakov, \\ V.L. Tatarintsev, L.M. Tatarintsev

\section{THE PROTECTION OF AGRICULTURAL GROUNDS IN ECONOMIC SUBJECT USING DIGITAL TECHNOLOGIES}

Крупочкин Евгений Петрович - канд. геогр. наук, доц., зав. каф. экономической географии и картографии Алтайского государственного университета, г. Барнаул.

E-mail: kafzem@bk.ru

Мерзляков Олег Эдуардович - канд. биол. наук, доц. каф. почвоведения и экологии почв Национального исследовательского Томского государственного университета, г. Томск.

E-mail: kafzem@bk.ru

Татаринцев Владимир Леонидович - д-р с.-х. наук, проф., руководитель стратегического проекта, проф. каф. экономической географии и картографии Алтайского государственного университета, г. Барнаул. E-mail: kafzem@bk.ru

Татаринцев Леонид Михайлович - д-р биол. наук, проф. каф. землеустройства, земельного и городского кадастра Алтайского государственного аграрного университета, г. Барнаул.

E-mail: kafzem@bk.ru

Главной задачей земельной политики РФ является сохранение и воспроизводство плодородия почв, качественных характеристик земель сельскохозяйственного назначения как важнейшего компонента окружающей среды и основного средства производства в сельском хозяйстве, а также разработка комплекса мероприятий по их охране. Решение проблемы охраны земель связано с организацией устойчивого развития всех объектов природной среды. Организация рационального природопользования связана с поиском баланса между агропромышленной эксплуатацией экосистем, их последовательной трансформацией и охраной. При моделировании различных комбинаций использования сельскохозяйственных угодий, которые являются основой сельскохозяй-
Krupochkin Evgeny Petrovich - Cand. Geogr. Sci., Assoc. Prof., Head, Chair of Economic Geography and Cartography, Altai State University, Barnaul.

E-mail: kafzem@bk.ru

Merzlyakov Oleg Eduardovich - Cand. Biol. Sci., Assoc. Prof., Chair of Soil Science and Soils Ecology, National Research Tomsk State University, Tomsk.

E-mail: kafzem@bk.ru

Tatarintsev Vladimir Leonidovich - Dr. Agr. Sci., Prof., Supervisor Strategic Projecting, Prof., Chair of Economic Geography and Cartography, Altai State University, Barnaul.

E-mail: kafzem@bk.ru

Tatarintsev Leonid Mikhaylovich - Dr. Biol. Sci., Prof., Chair of Land Management, Land and City Registry, Altai State University, Barnaul.

E-mail: kafzem@bk.ru

ственного землепользования, следует использовать современные иифровые технологии, способствующие лучшему пониманию предлагаемых проектных решений и учитывающие их качественные и количественные характеристики. В качестве исследуемой территории нами выбрано ОАО «Кипринское» Шелаболихинского района Алтайского края, в частности используемые в нем сельскохозяйственные угодья. На основании проведенного агроландшафртного анализа землепользования сельскохозяйственной организации составлены иисрровые картосхемы крутизны склонов, почвенная карта распределения земель по типам местности и типам урочищ, проведена сельскохозяйственная типология земель. В результате проведенной работы предложены 
мероприятия по охране сельскохозяйственных угодий исследуемого хозяйства, связанные с изменением структуры посевных площадей, севооборотов, агро- и лесохозяйственными мероприятиями, направленными на оптимизацию сельскохозяйственного землепользования.

Ключевые слова: охрана земель, сельскохозяйственные угодья, оптимизация землепользования, агроландшафотный анализ, иифризация сельского хозяйства, Алтайский край.

The main objective of land policy of the Russian Federation is the preservation and reproduction of soil fertility, qualitative characteristics of agricultural land as an essential component of the environment and the main means of production in agriculture, as well as the development of the set of measures for their protection. The solution of the problem of land protection is associated with the organization of sustainable development of all objects of the environment. The organization of natural environment is aimed at finding the balance between agrarian and industrial exploitation of ecosystems (rational use of natural resources), their protection and consistent transformation. When modeling various combinations of agricultural land use which are the basis of agricultural land use modern digital technologies should be used contributing to a better understanding of proposed design solutions and take into account their qualitative and quantitative characteristics. As the study area, JSC 'Kiprinskoe', Shelabolikhinsky district, Altai Region has been chosen, and, in particular, agricultural land used there. On the basis of conducted agrolandscape analysis of land use by an agricultural organization, digital cartographic diagrams of steepness of slopes, the soil map of distribution of lands on the types of district natural boundaries are made, agricultural typology of lands is carried out. As a result of carried out work, the actions for the protection of agricultural land of studied farm related to changes in the structure of cultivated areas, crop rotation, agricultural and forestry actions aimed at optimizing agricultural land use have been suggested.

Keywords: land protection, agricultural land, land use optimization, agrolandscape analysis, digitalization of agriculture, Altai Region.

Введение. Одной из целей Государственной программы развития сельского хозяйства и регулирования рынков сельскохозяйственной про- дукции, сырья и продовольствия на 2013-2020 годы является воспроизводство и повышение эфффективности использования в сельском хозяйстве земельных и других ресурсов, а также экологизация агропромышленного производства [1]. В сельском хозяйстве естественные ландшафрты посредством антропогенной деятельности трансформируются в агроландшафты, а они в свою очередь, являясь объектом природопользования, становятся объектом охраны [27]. Природоохранные мероприятия в отношении земельных ресурсов осуществляются посредством оптимизации агроландшафтов и организации устойчивых агроэкологических систем, начиная с общегосударственного уровня и заканчивая уровнем хозяйствующего субъекта в муниципальном районе [8-10]. Поэтому данная работа является актуальной и современной.

Цель исследования. Организация охраны сельскохозяйственного землепользования посредством агроэкологического анализа с использованием цифровых технологий.

Задачи: агроэкологический анализ сельскохозяйственного землепользования, создание цифровых карт, способствующих организации охраны сельскохозяйственных угодий.

Объекты и методы исследования. Объекты исследования: агроландшафты акционерного общества «Кипринское» Шелаболихинского муниципального района Алтайского края; процессы (эрозия и десрляция), тормозящие оптимальное природопользование. Основой исследования стали экологический и ландшафртный подходы, направленные на организацию адаптивного природопользования и сопряженные с агроэкологической оценкой земель. Системный подход использовали при анализе причинноследственных связей в агробиоценозах. Также использовались методы анализа и синтеза, дедукции и индукции.

Результаты и их обсуждение. Шелаболихинский район был образован в 1985 году. Территория находится в северной части Приобского плато. Он граничит с Сузунским районом (Новосибирская область), Тальменским, Павловским, Ребрихинским, а также Тюменцевским и Каменским районами Алтайского края.

Часть землепользования ОАО «Кипринское», согласно геоморфологическому районированию, разместилась в границах слабоволнистой рав- 
нины Приобского плато, другая часть - в пойме реки Оби. Территория хозяйства, помимо серьезной антропогенной нагрузки, подвержена воздействию водной эрозии и десрляции.

Согласно почвенно-географическому районированию, рассматриваемая нами сельскохозяйственная организация расположена в зоне черноземов в подзоне обыкновенных черноземов [11]. Преобладающими почвами являются обыкновенные черноземы $(21,4 \%$ от общей площади хозяйства), расположенные на выровненных и слабоповышенных участках, далее идут выщелоченные черноземы (16,4 \%), приуроченные к слабоволнистым и выровненным участкам слабоволнистой равнины. В пойме р. Оби распространены пойменно-луговые и пойменно-иловато-болотные почвы. Анализируемые природные характеристики землепользования сельскохозяйственной организации указывают на то, что оно является типичным для всей северной части Приобского плато и результаты исследований можно интерполировать на всю его территорию.
Площадь землепользования сельскохозяйственной организации составляет 26832 га, из которых, 21304 га - земли сельскохозяйственного назначения. На пашню приходится 9178 га, или $43 \%$ площади, на суходольные сенокосы 300 га, на пойменные - 5334 га, на суходольные и пойменные пастбища - 1532 и 4905 га соответственно, залежных земель нет, и 55 га составляют многолетние насаждения. Сельскохозяйственная организация занимается выращиванием зерновых и зернобобовых культур, а также в кодах ОКВЭД значится разведение крупного рогатого скота, деятельность агентов по оптовой торговле живыми животными, сельскохозяйственным сырьем, текстильным сырьем и полуфабрикатами, замороженными продуктами. По состоянию на 01.01.2018 прибыль ОАО составила более 55 млн руб.

На основе анализа эрозионных процессов, распространенных на территории землепользования ОАО «Кипринское», нами создана цифровая картосхема эродированных земель (рис. 1).

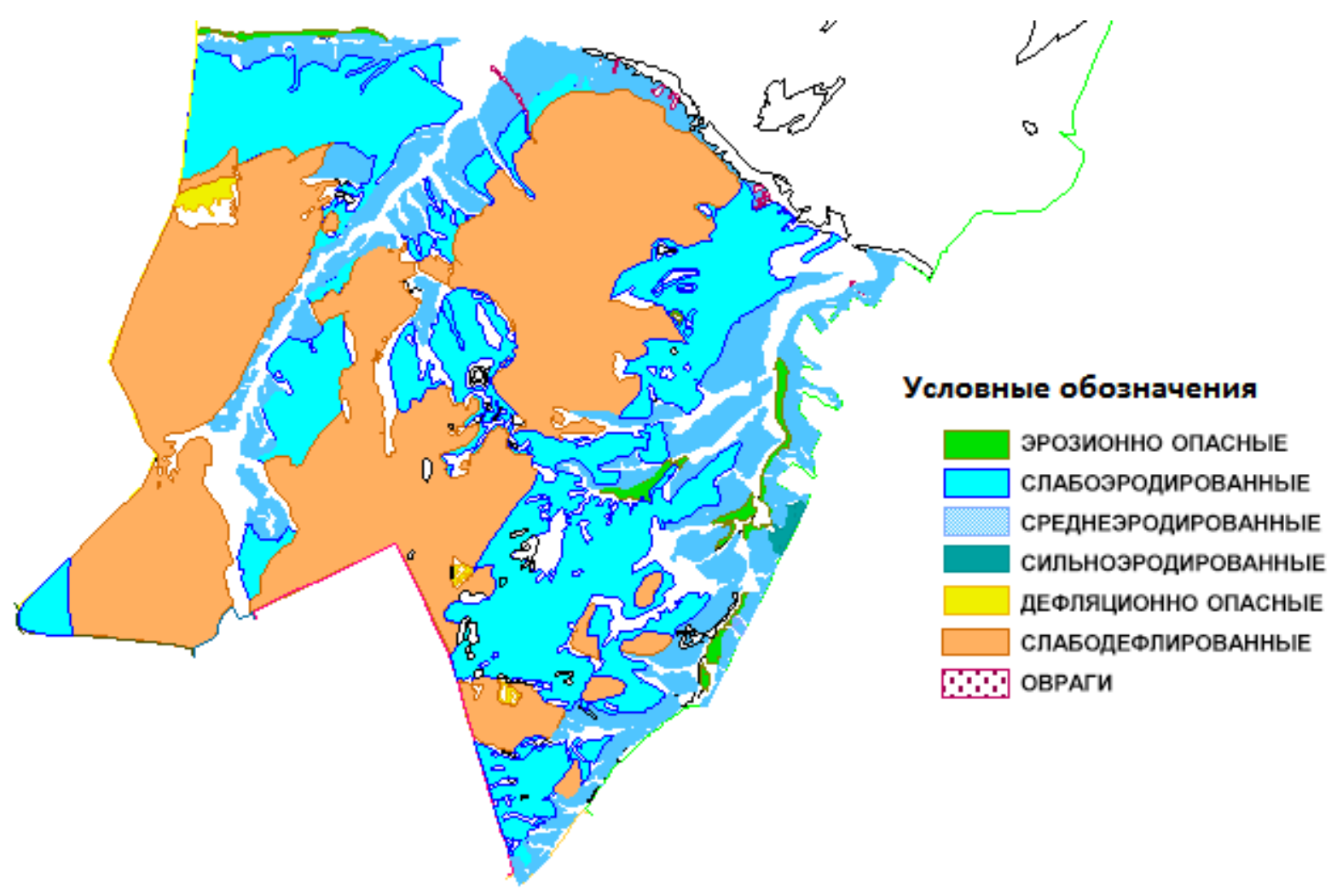

Puc. 1. Картосхема эродированных земель 
Водная эрозия и десрляция являются наиболее распространенными и активными на пахотных землях по сравнению с кормовыми угодьями. Эрозионно опасная пашня распространена почти на 40 \% от общей площади хозяйства, в том числе на слабосмытую пашню приходится более $33 \%$, а на среднесмытую - 6 \% площади. Дефляциионно опасной пашни в хозяйстве более $60 \%$, почти вся она отнесена к слабодефллированной.

К эрозионно опасным кормовым угодьям отнесено 84 \% территории сенокосов и почти полностью все пастбища. В основе своей все они размещены на слабо- и среднесмытых почвах. Также более 16 \% площади сенокосов размещены на дефляционно опасных землях.

Далее нами проведен анализ современного землепользования с точки зрения оценки его землеустроительной организации и влияния состава угодий на экологическую стабильность территории. В качестве экологических показателей были взяты общепринятые расчетные характеристики сельскохозяйственного землепользования, используемые при его экологической оценке [12]. Результаты представлены в таблице.

\section{Экологическая оценка землепользования}

\begin{tabular}{|l|c|c|c|c|c|c|}
\hline \multicolumn{1}{|c|}{ Земли } & $\begin{array}{c}\text { Распахан- } \\
\text { ность, } \\
\%\end{array}$ & $\begin{array}{c}\text { Сенокосы, } \\
\text { пастбища, } \\
\%\end{array}$ & $\begin{array}{c}\text { Лесис- } \\
\text { тость, } \\
\%\end{array}$ & $\begin{array}{c}\text { Соотноше- } \\
\text { ние пашни, } \\
\text { луга, леса, \% }\end{array}$ & $\begin{array}{c}\text { Коэф. } \\
\text { экол. } \\
\text { стаб. }\end{array}$ & $\begin{array}{c}\text { Коэф. } \\
\text { антр. } \\
\text { нагр., } \\
\text { балл }\end{array}$ \\
\hline $\begin{array}{l}\text { Земли сельскохозяйствен- } \\
\text { ного назначения }\end{array}$ & 34,2 & 45,0 & 7,6 & $34: 45: 8$ & 0,49 & 3,15 \\
\hline $\begin{array}{l}\text { Сельскохозяйственные } \\
\text { угодья }\end{array}$ & 43,0 & 56,6 & 0,4 & $43: 57: 0$ & 0,43 & 3,43 \\
\hline $\begin{array}{l}\text { Земли сельскохозяйствен- } \\
\text { ного назначения (без пой- } \\
\text { менных земель) }\end{array}$ & 67,8 & 13,5 & 14,1 & $68: 14: 14$ & 0,30 & 3,51 \\
\hline $\begin{array}{l}\text { Сельскохозяйственные } \\
\text { угодья (без пойменных зе- } \\
\text { мель) }\end{array}$ & 82,7 & 16,5 & 0,8 & $83: 17: 1$ & 0,23 & 3,82 \\
\hline
\end{tabular}

На основании проведенной агроэкологической оценки сельскохозяйственного землепользования можно констатировать, что оно подвержено высокой антропогенной нагрузке, а система земледелия, применяемая в хозяйстве, не только не защищает, но и способствует дальнейшей деградации как пахотных, так и кормовых угодий посредством водной эрозии и дефляции. Деградационные процессы, несбалансированность сельскохозяйственных угодий делают территорию экологически нестабильной.

Продолжили ландшафтно-структурный анализ территории, сопоставив данные по уклонам и типам местности, чтобы распределить земли сельскохозяйственной организации по типам урочищ. Выяснилось, что $54 \%$ площади ОАО размещено на землях с уклоном менее $1^{\circ}$, более $22 \%$ - с уклоном $1-2^{\circ}$, почти $10 \%$ - с уклоном $2-$ $3^{\circ}, 14 \%$ - уклон составил от 3 до $7^{\circ}$ (рис. 2). Коэффрициент расчлененности территории равен 2,3 кM/Км².

На основании типологического анализа землепользования нами выделено три типа общности рельефа, которые положены в основу выделения типов местности. В границах объекта исследования четко различаются пойменный, приречный и плакорный типы местности (рис. 3) $[13,14]$. 


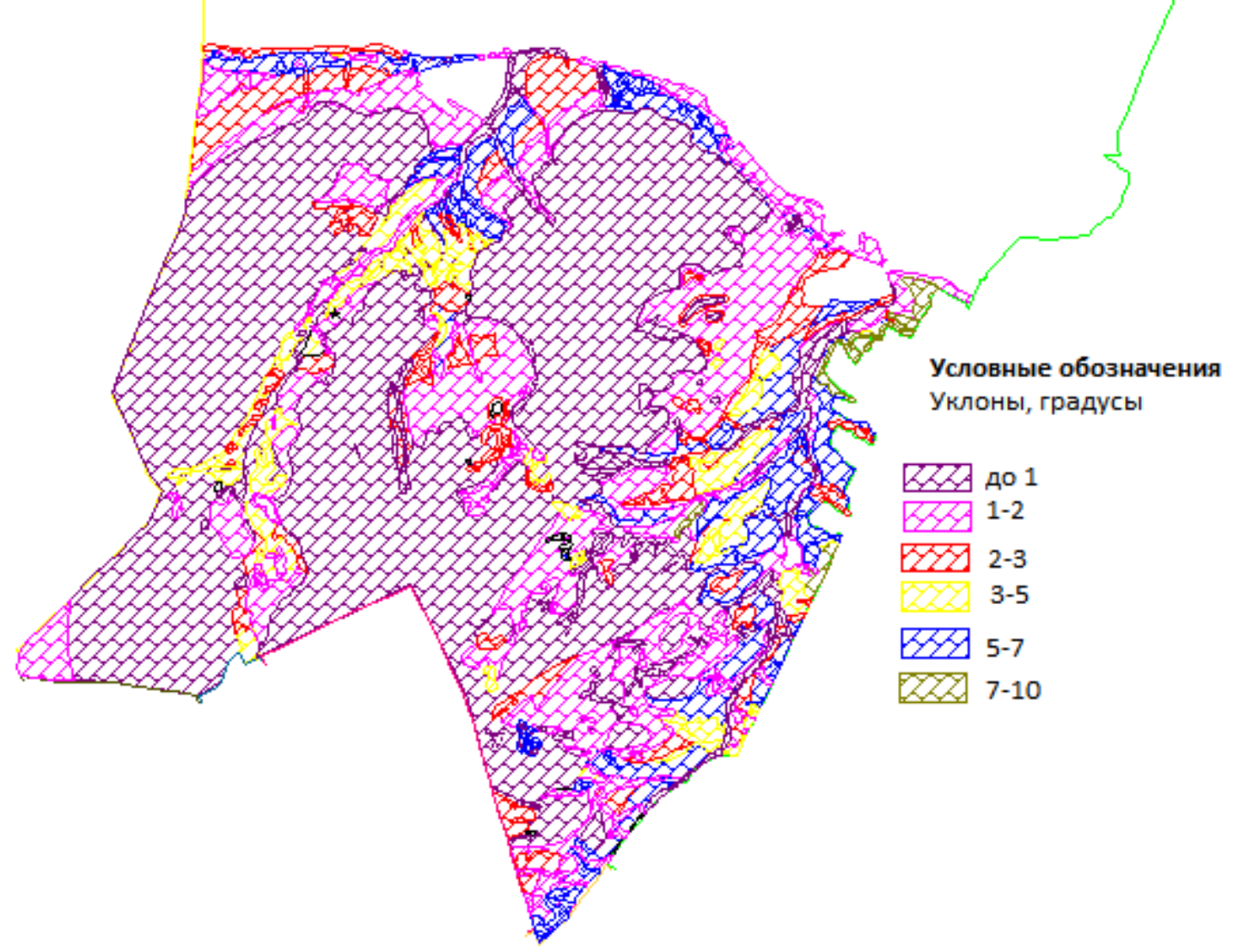

Puc. 2. Картосхема крутизны склонов

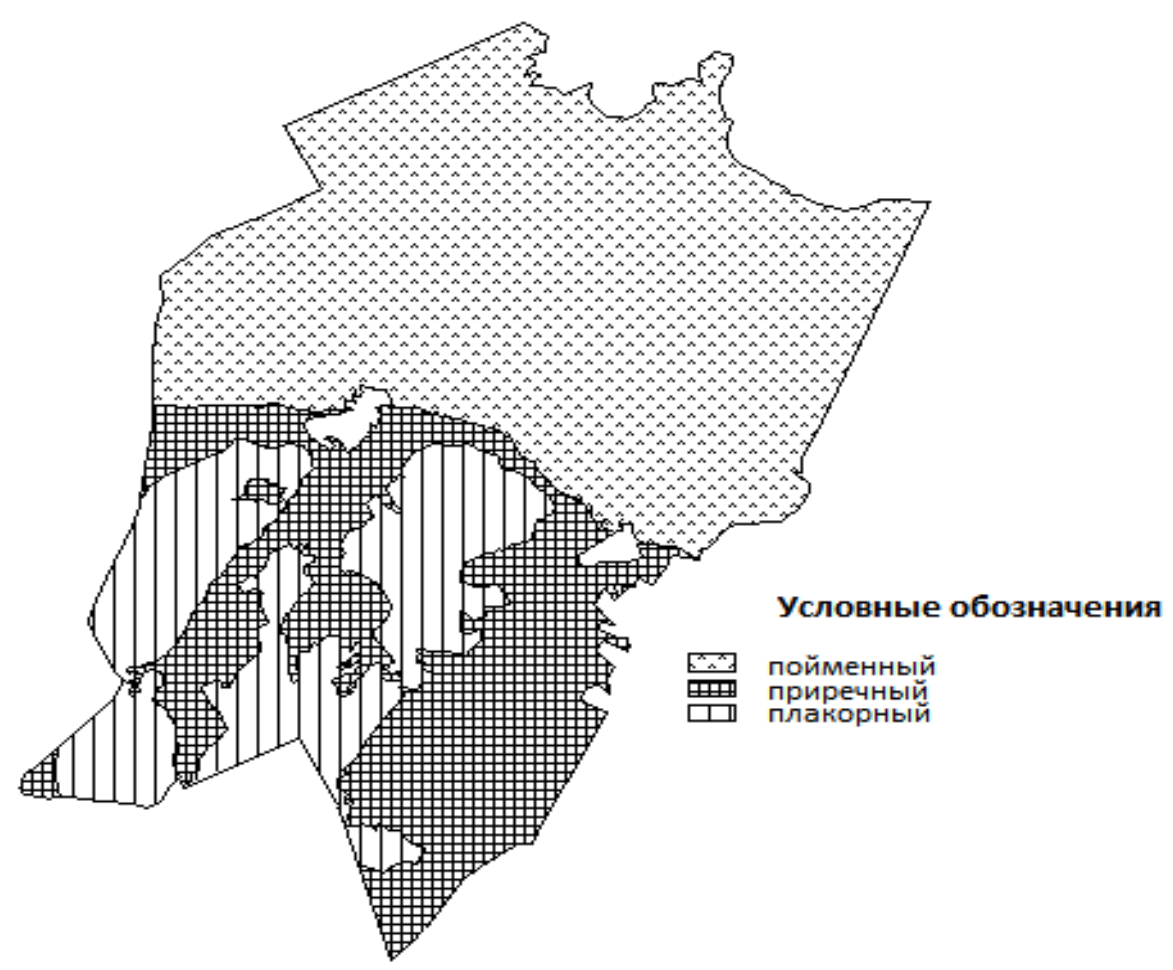

Puc. 3. Картосхема типов местности 
Плакорный тип местности является наиболее однообразным, несмотря на наличие колков и западин разного размера. В составе плакорного типа местности нами на территории землепользования выделены четырнадцать типов урочищ, а также сделано площадное и пространственное (цифрровая карта) распределение земель.

На основании выделенной нами совокупности агроэкологических фракторов необходимо провести их ранжирование с точки зрения лимитирующего влияния на возделывание сельскохозяйственных культур и возможностей их преодоления [15]. Факторы классифицируются по возможности управления ими на управляемые, регулируемые, ограниченно регулируемые и нерегулируемые.

Так как агроэкологические типы выделялись с учетом первичных элементов агроландшафта, то контуры сельскохозяйственных типов земель практически совпали с границами типов урочищ, однородных по почвенным разностям, крутизне и форме склона, интенсивности деградационных процессов, и стали однотипными по характеру сельскохозяйственного использования. В ряде случаев в границах нескольких урочищ пришлось выделить несколько типов земель.

Разделение территории хозяйства на типы земель нами проведено с применением ГИСтехнологий (программа Maplnfo), обеспечивших картографическую визуализацию результатов ландшафттн-экологической оценки. Посредством оцифровки картографических материалов масштаба 1:25000 были созданы электронные тематические карты-слои. В атрибутивных базах данных к каждой карте прилагаются площади выделенных контуров.

В результате цифровой типологизации было выделено 10 типов земель и составлена картосхема агроэкологических типов земель сельскохозяйственной организации (рис. 4).

Таким образом, анализируя типы земель, следует отметить, что первый тип ссрормировался на плакорных водораздельных пространствах (1-й тип урочищ). Он является наиболее благоприятным для производства полевых сельскохозяйственных культур. Второй, третий и четвертый типы земель расположены в грани- цах 7-го, 8-го и 9-го типов урочищ. К ним относятся земельные участки, подходящие под пахотные угодья, но имеющие определенные ограничения в использовании, связанные, например, с полосным размещением культур, посевами поперек склона, противоэрозионной обработкой территории, исключением из севооборотов пропашных культур, чистых паров, доведением соотношения площади полезащитных лесных полос до нормативного (1 га на 25 га сельскохозяйственных угодий). В четвертом и пятом типах земель, которые расположены на склонах 2-3 и 3-5 (9-й и 10-й тип урочищ), использование территории возможно только посредством проектирования почвозащитных севооборотов, содержащих от 50 до 70 \% трав от площади севооборота.

В одиннадцатом типе урочищ выделили VI и VII типы земель со склонами 4-7 , используемые под пастбища, и 7-10 - склоны, отнесенные к лесо-луговому типу, предназначенные также под пастбища, но с их защитой посредством лесополос для предотвращения эрозии. Днища балок (VIII тип земель, выделенный в пределах 12-го типа) следует использовать под улучшенные кормовые угодья (сенокосы и пастбища) с рекультивацией лесной растительности, которая раньше на этой территории занимала значительно бо́льшие площади и играла средостабилизирующую функцию.

В девятый природоохранный тип земель отнесены котловинно-западинные типы урочищ. Он по своему функционалу выполняет средостабилизирующую роль, защищая водоразделы и приводораздельные склоны от ветровой эрозии. Десятый тип земель включает в себя непригодные для сельского хозяйства территории, занятые оврагами, песками, оползневой зоной, и размещен на 13-м и 14-м типах урочищ. Овраги после проведения капиталоемких рекультивационных работ могут быть использованы в сельском хозяйстве как культурные сенокосы и пастбища в случае увеличения поголовья животных и роста потребности в кормах. Комплекс природоохранных мероприятий для пахотнопригодных типов земель ОАО «Кипринское» подробно описан в монографии Л.М. Татаринцева. 


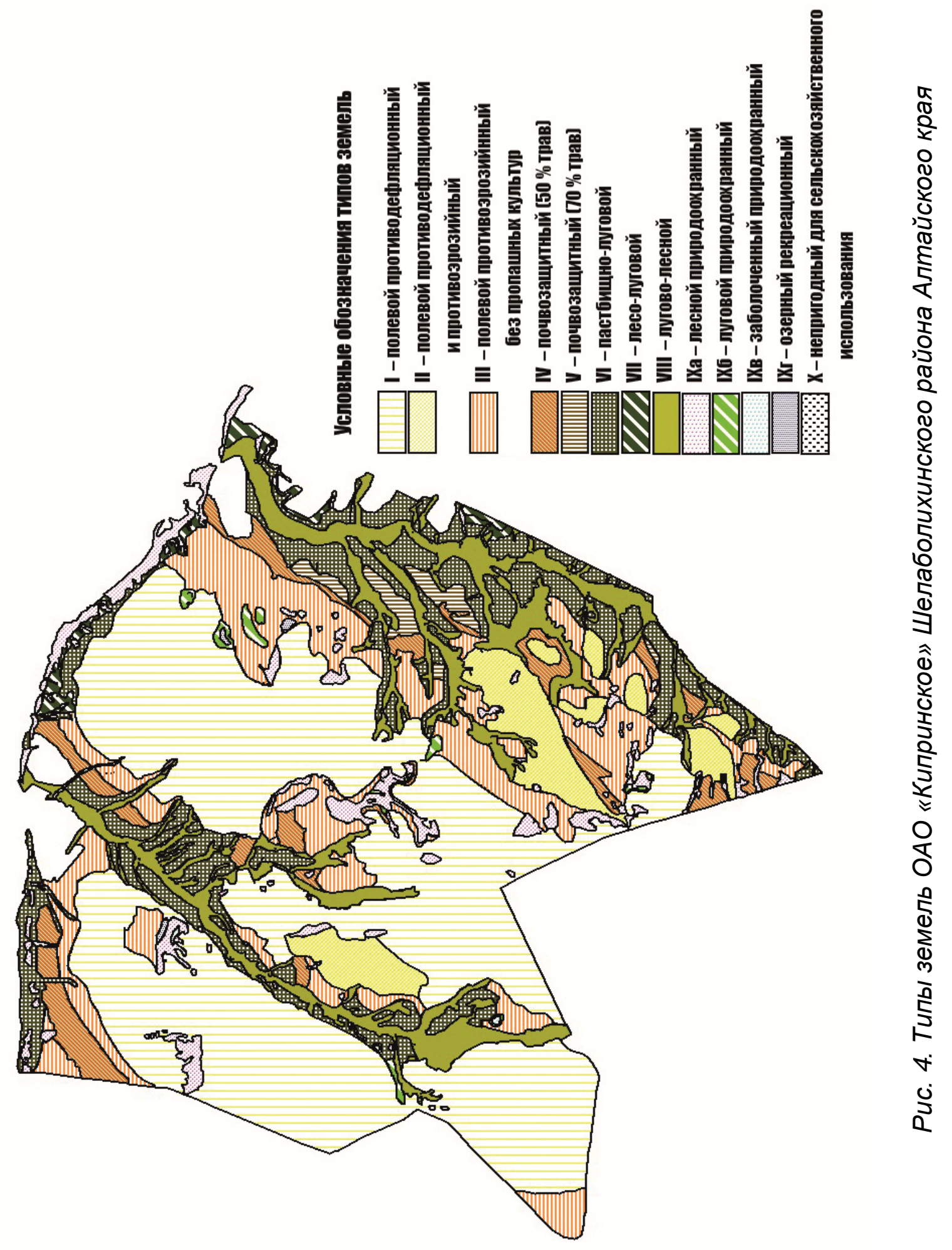


Заключение. Таким образом, в результате проведенной в работе цифровой типизации земель и анализа существующих агроландшафтов в границах выделенных типов нами предлагается проведение природоохранной трансформации эродированных и низкопродуктивных земель в кормовые угодья (сенокосы или пастбища, сообразно потребности) или лесные насаждения. В частности, под посадку сплошных лесонасаждений на сильносмытых, расчлененных овражно-балочной сетью землях (VI тип) следует вывести 22 га пашни. С этой же целью необходимо подверженные сильной и средней эрозии кормовые угодья на площади 86 га перевести в средостабилизирующие лесные насаждения. Распаханные балки (VII тип), занимающие площадь 196 га, рекомендуется перевести в залежь или высадить на них древеснокустарниковую растительность. В результате предложенного комплекса мероприятий площадь пашни в ОАО «Кипринское» уменьшится на $8 \%$, или 697 га, в результате чего произойдет ее качественная трансформация. Это повлияет на увеличение доли средостабилизирующих угодий, положительно отразится на экологических показателях состояния агроландшафртов и в конечном итоге сократит дополнительные затраты на низкопродуктивных угодьях и компенсирует упущенную выгоду от вывода из сельскохозяйственного оборота неэфффективной пашни [16-17].

\section{Литература}

1. Государственная программа развития сельского хозяйства и регулирование рынков сельскохозяйственной продукции, сырье и продовольствие на 2013-2020 годы. - URL: gosprog.ru/gp-razvitiya-selskogo-phozyayastval.

2. Арманд Д.Л. Наука о ландшафте. - М.: Мысль, 1975. - 288 с.

3. Добровольский Г.В., Гришина Л.А. Охрана почв. - М., 1985. - 224 С.

4. Агроэкологическая оценка сельскохозяйственного землепользования и мероприятия по его охране / А.Н. Дунец, О.А. Латышева, П.А. Мягкий [и др.] // Вестник КрасГАУ. 2019. - № 9. - С. 11-18.

5. Охрана сельскохозяйственных угодий $3 А О$ «Новоселовское» Красноярского края на основе эколого-ландшафтного зонирова- ния / Ю.В. Бадмаева, С.Э. Бадмаева, В.Л. Татаринцев [и др.] // Вестник КрасГАУ. - 2018. - № 5. - С. 329-334.

6. Латьшева О.А., Татаринцев В.Л., Татаринцев Л.М. Охрана земель: агроэкологический аспект (на примере Алтайского края): монографияя. - Барнаул: РИО Алтайского ГАУ, 2018. - 124 с.

7. Вольнов В.В., Давыдов А.С. Ландшафтоведение и агроландшафртные системы: учеб. пособие. - Барнаул: Изд-во АГАУ, 2006. $210 \mathrm{c}$.

8. Татаринцев В.Л., Татаринцев Л.М., Ткачук Е.C. Оптимизация структуры агроландшафтов и посевных площадей в Алтайской Кулунде // Вестник Алтайского государственного аграрного университета. - 2017. № 10 (156). - C. 43-49.

9. Повышение эффективности сельскохозяйственного землепользования в Алтайском крае / А.А. Бунин, О.А. Латьшева, В.Л. Татаринцев [и др.] // Вестник Алтайского государственного аграрного университета. - 2017. - № 5 (151). - С. 35-43.

10. Будрицкая И.А., Татаринцев В.Л., Татаринцев Л.М. Мероприятия по управлению и охране земель муниципального образования // Вестник Алтайского государственного аграрного университета. - 2014. - № 7 (117). - C. 165-170.

11. Почвенно-географическое районирование CCCP. - М., 1962. - 422 c.

12. Волков С.Н. Землеустройство. Землеустроительное проектирование. Внутрихозяйственное землеустройство: учеб. для вузов. - М.: Колос, 2001. - Т. 2. - 648 с.

13. Татаринцев В.Л. Гранулометрия агропочв юга Западной Сибири и их физическое состояние: монография. - Барнаул: Изд-во АГАУ, 2008. - $261 \mathrm{c}$.

14. Татаринцев Л.М., , Татаринцев В.Л., Кирякина Ю.Ю. Организация современного землепользования на эколого-ландшафтной основе. - Барнаул: Изд-во АГАУ, 2011. $120 \mathrm{c}$.

15. Кирюшин В.И., Иванов А.Л. Агроэкологическая оценка земель, проектирование адаптивно-ландшафтных систем земледелия и агротехнологий. - М.: ФГНУ «Росинфорагротех», 2005. - $784 \mathrm{c}$. 
16. Варламов А.А. Организация территории сельскохозяйственных землевладений и землепользований на экологоландшафтной основе: учеб. пособие. - М.: ГУЗ, 1993. - 114 с.

17. Бочаров С.Н., Татаринцев В.Л., Татаринцев Л.М. Агроэкологическая оценка сельскохозяйственного землепользования Алтайского края с целью увеличения его продуктивности // Вестник КрасГАУ. - 2020. № 1. - C. 18-26.

\section{Literatura}

1. Gosudarstvennaya programma razvitiya sel'skogo hozyajstva i regulirovanie rynkov sel'skohozyajstvennoj produkcii, syr'e i prodovol'stvie na 2013-2020 gody. - URL: gosprog.ru/gp-razvitiya-selskogo-rhozyayastva/.

2. Armand D.L. Nauka o landshafte. - M.: Mysl', 1975. - $288 \mathrm{~s}$.

3. Dobrovol'skij G.V., Grishina L.A. Ohrana pochv. - M., 1985. - $224 \mathrm{~s}$.

4. Agroekologicheskaya ocenka sel'skohozyajstvennogo zemlepol'zovaniya i meropriyatiya po ego ohrane / A.N. Dunec, O.A. Latysheva, P.A. Myagkij [i dr.] // Vestnik KrasGAU. 2019. - № 9. - S. 11-18.

5. Ohrana sel'skohozyajstvennyh ugodij ZAO «Novoselovskoe» Krasnoyarskogo kraya na osnove ekologo-landshaftnogo zonirovaniya / Yu.V. Badmaeva, S.E. Badmaeva, V.L. Tatarincev [i dr.] // Vestnik KrasGAU. - 2018. № 5. - S. 329-334.

6. Latysheva O.A., Tatarincev V.L., Tatarincev L.M. Ohrana zemel': agroekologicheskij aspekt (na primere Altajskogo kraya): monografiya. Barnaul: RIO Altajskogo GAU, 2018. - 124 s.

7. Vol'nov V.V., Davydov A.S. Landshaftovedenie i agrolandshaftnye sistemy: ucheb. posobie. Barnaul: Izd-vo AGAU, 2006. - $210 \mathrm{~s}$.

8. Tatarincev V.L., Tatarincev L.M., Tkachuk E.S. Optimizaciya struktury agrolandshaftov i posevnyh ploshchadej v Altajskoj Kulunde // Vestnik Altajskogo gosudarstvennogo agrarnogo universiteta. - 2017. - № 10 (156). - S. 43-49.

9. Povyshenie effektivnosti sel'skohozyajstvennogo zemlepol'zovaniya v Altajskom krae / A.A. Bunin, O.A. Latysheva, V.L. Tatarincev [l dr.] // Vestnik Altajskogo gosudarstvennogo agrarnogo universiteta. - 2017. - № 5 (151). S. 35-43.

10. Budrickaya I.A., Tatarincev V.L., Tatarincev L.M. Meropriyatiya po upravleniyu i ohrane zemel' municipal'nogo obrazovaniya // Vestnik Altajskogo gosudarstvennogo agrarnogo universiteta. - 2014. - № 7 (117). - S. 165-170.

11. Pochvenno-geograficheskoe rajonirovanie SSSR. - M., 1962. - $422 \mathrm{~s}$.

12. Volkov S.N. Zemleustrojstvo. Zemleustroitel'noe proektirovanie. Vnutrihozyajstvennoe zemleustrojstvo: ucheb. dlya vuzov. - M.: Kolos, 2001. - T. 2. - $648 \mathrm{~s}$.

13. Tatarincev V.L. Granulometriya agropochv yuga Zapadnoj Sibiri i in fizicheskoe sostoyanie: monografiya. - Barnaul: Izd-vo AGAU, 2008. - $261 \mathrm{~s}$.

14. Tatarincev L.M., Tatarincev V.L., Kiryakina Yu.Yu. Organizaciya sovremennogo zemlepol'zovaniya na ekologo-landshaftnoj osnove. - Barnaul: Izd-vo AGAU, 2011. - $120 \mathrm{~s}$.

15. Kiryushin V.I., Ivanov A.L. Agroekologicheskaya ocenka zemel', proektirovanie adaptivnolandshaftnyh sistem zemledeliya i agrotekhnologij. - M.: FGNU «Rosinforagrotekh», 2005. $784 \mathrm{~s}$.

16. Varlamov A.A. Organizaciya territorii sel'skohozyajstvennyh zemlevladenij i zemlepol'zovanij na ekologo-landshaftnoj osnove: ucheb. posobie. - M.: GUZ, 1993. - $114 \mathrm{~s}$.

17. Bocharov S.N., Tatarincev V.L., Tatarincev L.M. Agroekologicheskaya ocenka sel'skohozyajstvennogo zemlepol'zovaniya Altajskogo kraya s cel'yu uvelicheniya ego produktivnosti // Vestnik KrasGAU. - 2020. - № 1. - S. 18-26. 